\title{
Notes
}

\section{United Charities and the Sherman Act}

The old United Way slogan "Give once and give for all" expresses the fundamental appeal of the united charity system. ${ }^{1}$ To an American public besieged by requests for donations, the united charity approach offers a measure of relief and the legitimate response "I gave at the office." For businesses, a federated charity campaign reduces the workplace disruption that occurs when a steady stream of charities solicits donations from employees. And for member organizations, united charities constitute an economical fundraising system that assures them the respectability that stems from the monitoring procedures followed by most united charities.

To charities that are unable to join a united charity, however, these federations are a threat. Employers that allow united charities to solicit in the workplace frequently exclude unaffiliated charities. ${ }^{2}$ Employees who give at the office are understandably less generous when approached for the second or third (or thirtieth) time. In response, various groups have challenged several aspects of the united charity system. ${ }^{3}$

Some of the challenged practices restrain competition among producers of charitable services, thus raising a variety of antitrust issues. This Note explores the possible application of the Sherman Act to the conduct of united charities. The Note begins by examining the structure of the united charity system. ${ }^{4}$ It then describes the market for charitable services and

1. In this Note the term "united charity" refers to an organization that conducts joint fundraising on behalf of independent charities. The best known example of a united charity is the United Way of America, a federation of over 2000 local chapters that raises and distributes more than one billion dollars a year. See Cook, Is Charity Obsolete?, FORBES, Feb. 5, 1979, at 45.

2. Local chapters of the United Way of America enjoy exclusive access to almost $90 \%$ of the workplaces in which they solicit. See Wexler, Corporate Charity, NEW REPUBLIC, April 5, 1980, at 21.

3. See, e.g., National Black United Fund, Inc. v. Devine, 667 F.2d 173 (D.C. Cir. 1981) (rejection of application to participate in combined federal campaign); Moye v. Chrysler Corp., 465 F. Supp. 1189 (E.D. Mo. 1979) (employer's refusal to grant charity access to payroll deduction); International Serv. Agencies v. United Way, 108 Misc. 2d 305, 437 N.Y.S.2d 533 (Sup. Ct. 1981) (restrictions on participation in solicitation of state employees); Associated In-Group Donors v. United Way, Inc., No. C-233,112 (Cal. Super. Ct. filed Mar. 13, 1978) (refusal to allow charities to participate in separate joint campaigns).

4. The author's research in this section was aided greatly by discussions with Professor RoseAckerman, whose article United Charities: An Economic Analysis, 28 PUB. POL'Y 323 (1980), led this author to many of his sources. 
analyzes that market's inherent failures and the role that the Sherman Act should play in promoting the optimal provision of charitable services. The Note next considers the Sherman Act implications of several practices in which united charities have allegedly engaged; it concludes that although the Sherman Act does not preclude the formation of a united charity, it does prohibit such a charity from engaging in certain anticompetitive practices.

\section{The United Charity Controversy}

United charities exist to conduct joint fundraising on behalf of their members. ${ }^{5}$ Most such fundraising is done by means of the weekly payroll deduction system. ${ }^{6}$ Under that system, the united charity asks a company's employees to pledge a "fair share" of their weekly salary, which the employer automatically deducts from their weekly paycheck and gives to the united charity. The united charity distributes this money to its members in proportions determined by its allocations committee.

The payroll deduction system is an extremely efficient fundraising device. Because solicitations in the workplace tend to be disruptive, ${ }^{7}$ however, employers generally prefer to limit the number of charities they permit to solicit. The tension between the cost efficiency of payroll deductions and the disruption caused by workplace solicitation provided the original impetus for the creation of the single-fund drives that have evolved into united charities. ${ }^{8}$

In many cases, membership in a united charity is the only way to gain access to the payroll deduction system. As a result, some charities denied membership in a united charity are unable to survive. But many united charities only admit organizations that have proven their viability as independent charities for several years, ${ }^{9}$ thereby making it difficult for new

5. Most united charities focus their fundraising efforts on an annual solicitation drive. During that campaign, the united charity distributes materials to employees and sends representatives, usually volunteers, into workplaces to explain the united charity system. Employees that volunteer to help conduct the campaign usually do the actual solicitation of contributions. At the end of a campaign, the united charity typically gives awards to successful volunteers and to firms whose employees have a high rate of participation. See C. BAKAL, CHARITY U.S.A. 409-11 (1979).

6. The payroll deduction method of fundraising accounted for over $60 \%$ of United Way of America funds in 1979. See Wexler, supra note 2, at 20.

7. Shortly after World War II, the Ford Motor Co. computed that the average charity drive cost it \$40,000 in lost production. See Chernow, Cornering the Goodness Market: Uncharitable Doings at United Way, SATURDAY REV., Oct. 28, 1978, at 15, 16.

8. The payroll deduction system developed during World War II, when federal war-bond drives plagued American factories. The cost efficiency of the system quickly became clear, but businessmen objected to the disruption caused by a steady stream of fundraisers in the workplace. After the war, businessmen nationwide seized on the idea of a single-fund drive that would encompass all charitable donations. As united charities gradually evolved, many businesses granted them exclusive rights to solicit their employees. See id.

9. The United Way of Greater New Haven, for example, requires that an organization be at least 
charities to gain support. Others admit only agencies that operate on a national scale, thus excluding small charities that focus their efforts locally. ${ }^{10}$ In addition, many united charities openly acknowledge that membership in their organization is contingent upon the applicant's ability to appeal to shared values of the local community. ${ }^{11}$ This standard excludes many charities that address controversial issues such as desegregation, birth control, and worker safety. ${ }^{12}$

The exclusion of controversial organizations is in part a natural result of the common united charity practice of effectively preventing donors from allocating their gifts to a particular member charity. ${ }^{13}$ If a donor objects to a single charity within the package of charities represented by the united charity, he may decide to withhold his gift entirely. The risk of alienating potential donors gives united charities an economic incentive to deny membership to controversial agencies. ${ }^{14}$

The exclusivity of united charities has produced demands that their activities be constrained. ${ }^{16}$ Groups seeking membership in a united charity or direct access to the workplace have filed suits against united charities. ${ }^{16}$

three years old before it can apply for membership. See United Way of Greater New Haven, Manual of Policies and Procedures for United Way/Agency Relations (1979) (admissions section).

10. See, e.g., National Black United Fund, Inc. v. Campbell, 494 F. Supp. 748 (D.D.C. 1980) (finding national scope requirement for participation in federal charity drive overly broad and in violation of First Amendment ), rev'd sub nom. National Black United Fund, Inc. v. Devine, 667 F.2d 173 (D.C. Gir. 1981). A similar issue was raised by attempts of the Reagan Administration to restrict participation in the Combined Federal Campaign, which solicits federal employees. See Wash. Post, May 11, 1982, at A20, col. 1.

11. The head of the United Way of America, William Aramony, is quoted as saying: "By its very nature, the United Way cannot have extremes of left or right. It's a consensus system. And to that degree, you won't get a radical avant-garde position." Chernow, supra note 7, at 18 .

12. For example, until 1977 Planned Parenthood of Northwest Indiana received funding from its local United Way. In that year, its funding-which had risen to $\$ 64,000$ per year-was summarily terminated when Planned Parenthood announced plans to open an abortion clinic, even though the clinic was to be fully supported by patient fees. See id. at 16. In North Carolina and South Carolina, the Brown Lung Association recently picketed textile companies in which the United Way solicits exclusively; the Association objected to the refusal of 10 United Way chapters to fund the Association's local chapters. The Association claimed funds were denied because many representatives of the textile industry, a longtime opponent of the Association, serve on local United Way boards. National Commmittee for Responsive Philanthropy, Responsive Philanthropy 2 (Winter 1980) (newsletter).

13. See infra p. 1607 (describing allocations process).

14. In recent years, almost half of the United Way's support has gone to eight groups: the Red Cross, the Salvation Army, the Family Service Agency, settlement houses, the YMCA, the YWCA, Boys' Clubs, and the Boy Scouts. Cook, supra note 1, at 45. This clustering is remarkable considering that the funds are allocated by 2200 separate campaigns. Chernow, supra note 7 , at 16 .

15. The tension that united charities create is heightened by the financial difficulties currently facing many charities. The number of charities has increased dramatically in recent years, but the volume of donations has only kept pace with inflation. See U.S. NEWS \& WORLD REP., May 18, 1981, at 18. Thus, competition among charities has become increasingly fierce. As a result, the yield from many forms of fundraising has dropped dramatically, see Cook, supra note 1, at 48-51 (competition among charities increasing), causing the fundraising costs of most charities to increase significantly.

16. See National Black United Fund, Inc. v. Devine, 667 F.2d 173 (D.C. Cir. 1981); United Black Fund, Inc. v. Hampton, 352 F. Supp. 898 (D.D.C. 1972). 
Donors have also sought legal redress for their inability to give to the charity of their choice through the payroll deduction system. ${ }^{17}$ These suits have been based on a wide variety of legal grounds. ${ }^{18}$ In very few instances, however, have the parties recognized the potential of the Sherman Act $^{29}$ as a basis for their suits. ${ }^{20}$

The central purpose of the Sherman Act is to promote consumer welfare, ${ }^{21}$ which is desirable in the charity and nonprofit sectors as well as in the for-profit sector. Nothing in the language of the Act prevents its application to the nonprofit or charity sectors. ${ }^{22}$ Moreover, implicit exemptions

17. See Moye v. Chrysler Corp., 465 F. Supp. 1189 (E.D. Mo. 1979).

18. Many of the suits have been brought on constitutional grounds. See City of Charlotte v. Local 660, Int'l Ass'n of Firefighters, 426 U.S. 283 (1976) (refusal to grant payroll deductions for union dues when allowed for United Way does not violate equal protection); National Black United Fund, Inc. v. Campbell, 494 F. Supp. 748 (D.D.C. 1980) (combined Federal Campaign regulations violate First and Fifth Amendments), rev'd sub nom. National Black United Fund, Inc. v. Devine, 667 F.2d 173 (D.C. Cir. 1981); Moye v. Chrysler Corp., 465 F. Supp. 1189 (E.D. Mo. 1979) (refusal to allow United Black Community Fund to solicit in workplace where United Way solicits does not violate either Fifth or Fourteenth Amendments).

19. 15 U.S.C. $\S \S 1-7$ (1976).

20. A few suits have been brought under state antitrust statutes. International Serv. Agencies v. United Way, 108 Misc. 2d 305, 437 N.Y.S.2d 533 (Sup. Ct. 1981); Associated In-Group Donors v. United Way, No. C-233,112 (Cal. Super. Ct. filed Mar. 13, 1978); California State Combined Health Agencies Drive, Inc. v. United Way, No. 382,156 (Cal. Super. Ct. filed Aug. 16, 1977).

21. R. BORK, THE ANTITRUST PARADOX 50-89 (1978). Although most commentators would agree that consumer welfare is a central concern of the Act, some commentators suggest that the Act should, or does, reflect other goals as well. See L. SULLIVAN, HANDBOOK OF THE LAW OF ANTITRUST $\S 2$ (1977) (other purposes include "a preference for decentralization of economic power, . . . [and] a nostalgia for that mythical past when social, governmental and economic organization was simpler, more comprehensible"); Elzinga, The Goals of Antitrust: Other Than Competition and Efficiency, What Else Counts?, 125 U. PA. L. REV. 1191, 1194-202 (1977) (listing goals as redistribution of income, promotion of small enterprises, and liberty of entrepreneurs). Compare Blake \& Jones, In Defense of Antitrust, 65 COLUM. L. REV. 377, 382-84 (1965) (listing goals as minimization of political interference and enlargement of individual liberty) and Blake \& Jones, Toward a Three-Dimensional Antitrust Policy, 65 Colum. L. REV. 422, 425-36 (1965) (same) with Bork, Contrasts in Antitrust Theory: I, 65 ColuM. L. REV. 401, 412-15 (1965) (limiting goals to maximization of efficiency) and Bork \& Bowman, Crisis in Antitrust, 65 ColuM. L. REV. 363 (1965) (same).

22. The Sherman Act regulates commerce that affects "trade or commerce among the several States." 15 U.S.C. $\S \S 1,2$ (1976). In determining whether a particular practice is "commercial," courts have consistently denied a blanket antitrust immunity for nonprofits based on charitable purpose or organizational form. See infra note 24. Instead, courts have examined the nature of the particular practice under challenge. Under this approach, courts have held that legal services, for example, fall within the statutory definition of commerce. Goldfarb v. Virginia State Bar, 421 U.S. 773 (1975) (legal profession not immune from Sherman Act). When nonprofit organizations negotiate contracts and make profit-motivated decisions, courts consider the practice commercial. Hennessey v. National Collegiate Athletic Ass'n, No. CA 76-P-0799-W (N.D. Ala. Sept. 27, 1976), reprinted in 564 F.2d 1141 (millions of dollars obtained by negotiating television contracts and selling tickets evidence that some aspects of National Collegiate Athletic Ass'n were commercial), aff'd per curiam, 564 F.2d 1136 (5th Cir. 1977).

Charitable solicitation has many commercial features. Competing charities campaign aggressively to sell their charitable services to the public. In setting up united charities, participating members frequently bargain among themselves to determine the relative size of each other's allocations. These bargains reflect revenue-maximizing negotiations. See Cook, supra note 1, at 46 (United Way chapters in Dallas, Los Angeles, Honolulu, and Cleveland have special arrangements with Heart Ass'n and Cancer Soc'y "to guarantee them a minimum take, with the understanding that they won't run competing campaigns."). 
from the Sherman Act are strongly disfavored..$^{23}$ Indeed, courts have already held some nonprofit activities subject to the Sherman Act. ${ }^{24}$

But in using the Sherman Act to regulate the charity sector, rules of structure and conduct developed in the for-profit sector may not be appropriate. ${ }^{28}$ Various institutional factors differ between the two sectors, as do many cost and demand conditions. To appreciate such differences requires an understanding of the economics of the charity sector.

23. See, e.g., United States v. Philadelphia Nat'I Bank, 374 U.S. 321, 350-53 (1963) (federal regulation of banking does not exempt banks from antitrust laws); Silver v. New York Stock Exchange, 373 U.S. 341 (1963) (authority to regulate securities does not exempt stock exchange rules from antitrust). In the absence of a statutory exemption, courts have found the antitrust laws inapplicable only when they conflicted with other policies of profound national importance. See, e.g., United Mine Workers v. Pennington, 381 U.S. 657, 669-70 (1965) (recognizing implicit exemption for attempts to solicit government action); Eastern R.R. Presidents Conference v. Noerr Motor Freight, Inc., 365 U.S. 127, 135-45 (1961) (same); Parker v. Brown, 317 U.S. 341, 350-52 (1943) (establishing implicit exemption from antitrust laws, rooted in principles of federalism, for actions by states). The stringency of courts regarding exemptions reflects the perception that if Congress wants certain activities to enjoy antitrust immunity, it can so provide. Congress has, for example, explicitly exempted "charitable institutions not operated for profit" from the prohibition on price discrimination contained in the Robinson-Patman Amendments to the Clayton Act. 15 U.S.C. $\S 13$ (c) (1976).

24. For examples involving amateur athletics, see Warner Amex Cable Communications, Inc. v. American Broadcasting Co., Inc., 499 F. Supp. 537 (S.D. Ohio 1980) (National Collegiate Athletic Ass'n exclusive television contract with national network subject to challenge); Hennessey v. National Collegiate Athletic Ass'n, No. CA 76-P-0799-W (N.D. Ala. Sept. 27, 1976), reprinted in 564 F.2d 1141 (National Collegiate Athletic Ass'n by-law limiting number of coaches certain schools could hire subject to challenge), affd per curiam, 564 F.2d 1136 (5th Cir. 1977); Tondas v. Amateur Hockey Ass'n of United States, 438 F. Supp. 310 (W.D.N.Y. 1977) (amateur hockey subject to antitrust laws). For examples involving the learned professions, see Arizona v. Maricopa County Medical Soc'y, 102 S. Ct. 2466 (1982) (striking down society's maximum-fee schedule as illegal per se); National Soc'y of Professional Eng'rs v. United States, 435 U.S. 679 (1978) (striking down association by-law limiting competitive bidding); Goldfarb v. Virginia State Bar, 421 U.S. 773 (1975) (striking down minimum fee schedule put out by state bar); Boddicker v. Arizona State Dental Ass'n, 549 F.2d 626 (9th Cir.) (requirement of membership in national association not immune), cert. denied, 434 U.S. 825 (1977). Educational institutions have been found exempt in the past, see Marjorie Webster Junior College, Inc. v. Middle States Ass'n of Colleges \& Secondary Schools, 432 F.2d 650 (D.C. Cir.), cert. denied, 400 U.S. 965 (1970), but the rationale expressed in Goldfarb would seem to preclude such holdings in the future.

25. In the for-profit sector, restraints of trade are analyzed using two standards: the rule of reason and the per se doctrine. The rule of reason applies to restraints of trade that may be justifiable under some conditions because their net effect is to enhance competition and thereby improve allocative efficiency. See, e.g., Chicago Bd. of Trade v. United States, 246 U.S. 231, 238 (1918); Standard Oil Co. v. United States, 221 U.S. 1, 63-66 (1911). The per se doctrine applies to practices that have no beneficial effect upon competition and that are therefore illegal in all cases. See, e.g., United States v. Socony-Vacuum Oil Co., 310 U.S. 150, $218-22$ (1940) (price fixing); United States v. Trenton Potteries, 273 U.S. 392, 396 (1927) (same).

Courts have recognized that the existence of noncommercial objectives in certain areas of commerce may require that a practice be treated differently than it would be in traditional for-profit activities. See, e.g., National Soc'y of Professional Eng'rs v. United States, 435 U.S. 679, 686-96 (1978); Goldfarb v. Virginia State Bar, 421 U.S. 773, $788-89$ n.17 (1975) ("[I]t would be unrealistic to view the practice of professions as interchangeable with other activities, and automatically to apply to the professions antitrust concepts which originated in other areas."); Hennessey v. National Collegiate Athletic Ass'n, No. CA 76-P-0799-W (N.D. Ala. Sept. 27, 1976), reprinted in 564 F.2d 1141 (analyzing National Collegiate Athletic Ass'n by-law with "marked similarity to an agreement for allocation of "market shares" "under rule of reason even though it would be illegal per se in for-profit sector), affd per curiam, 564 F.2d 1136 (5th Cir. 1977). 


\section{The Economics of the Charity Sector}

To obtain Pareto optimality ${ }^{26}$ in a market composed of for-profit firms, certain conditions must be met. When these conditions are not met, alternative institutions may replace the for-profit market. ${ }^{27}$ The nonprofit firm is one institution that has emerged in sectors where transactions between buyers and for-profit sellers do not lead to Pareto optimality. ${ }^{28}$ The charity sector is a sector in which the nonprofit firm has flourished. ${ }^{28}$

\section{A. The Demand for Charitable Services}

\section{The demand side of the charity market consists of donors willing to pay}

26. Pareto optimality provides a definition of allocative efficiency. An allocation of resources is Pareto optimal if production and distribution cannot be altered to increase the utility of any individual without decreasing the utility of others. J. HENDERSON \& R. QUANDT, MICROECONOMIC THEORY 255 (1958).

Allocative efficiency depends on three conditions: efficiency in production, efficiency in distribution, and consumer sovereignty. For a detailed explanation of these concepts, see Scherer, General Equilibrium and Economic Efficiency, 10 AM. ECONOMIST 1 (1966).

27. Government-operated firms, such as Amtrak, and government regulation are two common responses to failures of for-profit markets.

28. Nonprofit firms often supplant their for-profit counterparts when a purchaser cannot evaluate the service that is purchased. This may happen for two reasons. First, the recipient of the good may not be the same person as the purchaser. See, e.g., Hansmann, The Role of Nonprofit Enterprise, 89 YALE L.J. 835, 846 (1980) (illustrating this problem using example of services provided overseas by CARE); Nelson \& Krashinsky, Public Contract and Economic Organization of Day Care for Young Children, 22 PUB. POL'Y 53, 66-69 (1974) (explaining preeminence of nonprofit firms in day-care business as result of inability of parents to evaluate quality of services provided). Second, the good being purchased may be a public good. Public goods cost no more to provide for many people than for a single person, and their benefits cannot be reserved to the individuals who pay for their production. National defense and clean air are typical examples. See R. MUSGRAVE \& P. MUSGRAVE, Public FINANCE IN THEORY AND PRACTICE 49-80 (2d ed. 1976) (describing and discussing public goods); Hansmann, supra, at 848-51 (discussing problem of public goods using commercial-free broadcasting as example).

Under either of these circumstances, an individual who contracts with a for-profit firm finds it difficult to enforce the terms of his agreement. When the purchaser is not also the recipient, the purchaser may not be able to tell what quality of service was provided or even whether the service was provided at all. A for-profit firm would have an incentive to economize on the service provided and to take advantage of the donor's inability to enforce his agreement. Hansmann, supra, at 835; Nelson \& Krashinsky, supra, at 66-69. In the case of public goods, the difficulty of evaluating services results from the indivisible nature of the service. The consumer cannot tell whether his contribution improved the service or increased the profits of the producers. For-profit firms would have an incentive to request contributions far in excess of the amount required to pay for the service. Hansmann, supra, at 848-51.

A nonprofit organization is, by definition, barred from distributing its net earnings to individuals who exercise control over it. This legal constraint reduces the incentive for a firm to exploit the purchaser's inability to police his bargain by providing low quality services. The nondistribution constraint also assures donors that their contribution will increase the output of the service they wish to support. Id. at 843-54.

29. For purposes of this Note, "charities" are a subset of the more inclusive "nonprofits." Charities are organizations that receive most of their income from grants or donations and that have as their purpose the promotion of social welfare. "Nonprofits" include a much wider assortment of organizations, ranging from country clubs to labor unions. See Hansmann, supra note 28, at 840-43 (constructing four-class categorization of nonprofits, two of which are described as "donative nonprofits," which this Note refers to as charities). 
for the production of charitable services. Although contributions to charities may appear to be unilateral transfers, they are actually payments in return for which the donor receives something of value. The donor may gain satisfaction from helping a particular group of beneficiaries, or he may feel a more generalized sense of status, community, or relief from guilt. $^{\text {so }}$ An individual's gift to a charity represents an allocation of his wealth to the services provided by the charity, and away from other goods and services. The quantity and variety of charitable services that an individual purchases with charitable donations depends on the marginal satisfaction he would gain by purchasing other goods. Because charitable donations are consumption purchases, each individual can be expected to donate to a given charity up to the level at which the utility he receives from the last dollar he donates is equal to the utility he would have received from either donating that dollar to another charity or spending it on some other good. ${ }^{31}$

Because the utility derived by an individual who makes a charitable donation is partially attributable to a generalized sense of altruism, ${ }_{2}^{32}$ competition in a charity market extends beyond the set of firms that provides a particular charitable service. The degree of substitutability between different charitable services is an empirical issue that must be resolved on a case-by-case basis when a market must be defined..$^{33}$ In the abstract, how-

30. For present purposes, it is sufficient to say that donors give to charities up to the level that maximizes their utility, although such a statement is so formal as to border on tautology. More helpful information would be the composition of the utility functions of individual donors. See generally T. IRELAND \& D. JOHNSON, THE ECONOMICS OF CHARITY 19-22 (1970) (suggesting five different motivations underlying donations: direct personal benefits, satisfaction from seeing others benefitted, enjoyment from act of giving, desire for political approval, and compliance with condition of employment); Arrow, Gifts and Exchanges, in ALTRUISM, MORALITY AND ECONOMIC THEORY 18 (E. Phelps ed. 1975) (reviewing different theories concerning the rationality of altruism); Boulding, Notes on a Theory of Philanthropy, in PhILANTHROPY AND PUBLIC POLICY 57 (F. Dickinson ed. 1962); Schall, Interdependent Utilities and Pareto Optimality, 86 Q.J. ECON. 19 (1972) (discussing utility functions in which utility of person $A$ is in part function of utility of person B); Schwartz, Personal Philanthropic Contributions, 78 J. POL. ECON. 1264 (1970) (same); Scott, Avarice, Altruism, and Second Party Preferences, 86 Q.J. ECON. 1 (1972) (same).

31. See R. DORFMAN, PRIGES AND MARKETS 140-42 (1978) (individual's allocation of wealth depends on relative marginal utilities of different uses); Scott, supra note 30, at 1-6 (discussing utility function of altruistic individuals); S. Rose-Ackerman, Charitable Giving and "Excessive" Fundraising 4 (Yale University, Institution for Social \& Policy Studies, Program for Non-Profit Organizations, working paper no. 26, 1980) (giving depends on relative marginal utilities of different uses).

32. See T. IRELAND \& D. JOHNSON, supra note 30 (describing motivations for giving); Schall, supra note 30 (discussing interdependent utility functions); Schwartz, supra note 30, at 1264-68, 1289-91 (same).

33. Market definition is a central aspect of many antitrust cases because it forms the basis for an analysis of whether market power exists. The ideal definition of a market must take into account the substitution possibilities for both demand and supply (that is, cross-elasticity). For a discussion of cross-elasticity of demand, see United States v. E.I. du Pont de Nemours \& Co., 351 U.S. 377, 39395 (1956) (applying cross-elasticity concept of market definition); R. POSNER, ECONOMIC ANALYSIS OF LAW 221-23 (2d ed. 1977) (explaining severe practical limitations on application of cross-elasticity concept); F. SCHERER, INDUSTRIAL MARKET STRUCTURE AND ECONOMIC PERFORMANCE 60-61 (1980) (discussing theoretical concepts in market definition and practical difficulties of actually defin- 
ever, one might expect many donors to feel a high level of substitutability between hunger-relief charities; for other donors, health-related charities may be highly substitutable; for others, charities that promote some interest of a particular ethnic or religious group would be substitutable. The amount of aggregate substitutability among charitable services depends to a large extent on the cross-cutting interests of a community of donors. These preferences can be determined only through observation of a given set of donors.

\section{B. The Supply of Charitable Services}

The supply side of the charity market consists of the nonprofit organizations that produce charitable services. Although the inability of charities to distribute profits removes one incentive for the supply of charitable services, a variety of factors may motivate entrepreneurs and managers to enter the charity sector. ${ }^{34}$ Some may derive satisfaction from the fact that a firm produces services without regard for the profit the services yield. Others may derive satisfaction from providing certain services that only charities provide ${ }^{35}$ or from influencing the provision of such services. Still others, who have no capital to invest and who need employment, may enter the charity sector for purely monetary gain.

In the absence of competition, it is likely that the services offered by charities will differ significantly from those that donors desire for the following reasons: first, the managers of a charity may derive satisfaction directly from the provision of specific services that differ from the services desired by donors ${ }^{36}$ second, entry into the charity sector may not be fast enough to respond fully to donors' desires; and third, information about services provided by other charities may not be sufficient for donors to transfer their patronage among firms.

Of course, the managers of a charity cannot wholly neglect the desires

ing markets). For a discussion of cross-elasticity of supply, see id. at 60-61.

34. See Hansmann, supra note 28, at 876, 899-901; B. Weisbrod, Economics of Institutional Choice, (Conference on Institutional Choice and the Private Nonprofit Sector, University of Wisconsin, Madison, Oct. 1979) (differences between supply of nonprofit and for-profit goods and services). In order to distinguish among the qualities of entrepreneurship that are found in different segments of the economy, Hansmann and Weisbrod postulate a "screening process" that filters entrepreneurial individuals into different sectors according to their own personalities and the structural characteristics of the different sectors. Young carries the analysis a step further by examining different sectors at the industry level according to four properties: the character of the services produced, the degree of control by the professions, the degree of economic concentration, and the social priority attached to the field. D. Young, Entrepreneurship and the Behavior of Nonprofit Organizations: Elements of a Theory (Yale University, Institution for Social \& Policy Studies, Program for Non-Profit Organizations, working paper no. 4,1980 ).

35. For example, someone interested in easing the problem of world hunger might enter the nonprofit sector because that sector does most of the work in that field.

36. In the for-profit sector, the profit motive causes firms to respond quickly to consumer desires. See Scherer, supra note 26 (discussing consumer sovereignty). 
of their benefactors; they must please the benefactors enough to attract sufficient donations to keep the firm in operation. As a result, an implicit bargain emerges between the managers of a charity and the donors concerning the services to be provided. ${ }^{37}$ The more alternative charitable services available to donors, the less divergence there will be between the services donors desire and those provided. An efficient charity sector will produce precisely the charitable services that the donor population wishes, and as much of them as donations can cover.

For a variety of reasons, therefore, competitive conditions will benefit donors even though charities are not profit-making institutions. First, competition will cause charities to minimize their costs for the services they provide, ${ }^{38}$ because donors can be expected to give to the charities that use donations most efficiently. ${ }^{39}$ Free entry into the charity market strengthens the incentive for firms to minimize their costs. Second, firms facing competition will tend to produce at the level of output for which average cost per unit is at its minimum, which is also the level at which average cost and marginal cost are equal..$^{40}$ When existing firms operate above this level, even if they produce efficiently, new charities will tend to enter the market and offer donors more services per dollar of donation. These two benefits of competition together enable donors to maximize the quantity of desired charitable services provided by their donations.

\section{The Application of the Sherman Act to United Charities}

The beneficial results of competition in the charity sector make it socially desirable to have many charities in competition with each other. At the same time, however, certain aspects of producing charitable services,

37. A charity that provides a service for which donors have no close substitutes occupies a position analogous to that of a monopolist in the for-profit sector. In the same way that a for-profit monopolist has leeway to raise its price to increase profits, the monopolist charity can vary the nature of its service to increase the particular utilities of those who control the firm.

38. This type of efficiency is sometimes referred to as "x-efficiency." For a fuller explanation of this term, see Liebenstein, Allocative Efficiency vs. "X-Efficiency," 56 AM. ECON. REv. 392 (1966); see also F. SCHERER, supra note 33, at 464-65 (discussing x-inefficiencies).

39. This condition depends upon the donors having some information about the charitable service they support. It does not, however, depend upon their having perfect or near-perfect information. The inadequacy of such information provides one explanation for the dominance of nonprofit firms over for-profit firms in many markets. See supra p. 1598.

Most donative charities cooperate with one of three watchdog agencies that do provide information to donors: the National Information Bureau, in New York; the Evangelical Association for Financial Accountability, in Chicago; and the Philanthropic Advisory Service, in Washington, D.C. These agencies provide such information as the percentage of funds absorbed in fundraising, the percentage of total funds spent on the programs for which the funds were raised, and the percentage of total funds retained as unexpended income. See Cook, supra note 1, at 50. This information, however, is not circulated very widely.

40. For a fuller discussion of the importance of market entry for achieving allocative efficiency in a charity market, see Appendix. 
such as fundraising, are characterized by significant and socially desirable economies of scale. For that reason certain forms of cooperation among charities are justifiable under a rule of reason analysis. The Sherman Act permits cooperation among competitors only if the benefits that result outweigh the inefficiencies that reduced competition creates. ${ }^{41}$ The proper application of the Sherman Act to charities depends on distinguishing between practices that produce economies of scale or other benefits and practices that restrain competition without providing greater compensating social benefit.

\section{A. The Efficiencies of a United Charity}

The principal efficiencies created by united charities lie in two general areas. First, united charities greatly reduce the costs of solicitation. It costs much less, for example, to have one person collect money for many charities than to have each charity send a separate representative to solicit each potential donor. ${ }^{42}$ In addition, united charities reduce the harassment of donors that would result if all individual charities conducted independent campaigns. Moreover, because united charities reduce the workplace disruption caused by charity drives, they make employers more willing to sponsor the payroll deduction system.

Second, the existence of united charities lessens the problem of imperfect information among donors. ${ }^{43}$ Poor information lowers the utility that a donor derives from making a charitable contribution and deters dona-

41. See supra note 21 (describing economic efficiency as major goal of Sherman Act); note 25 (explaining rule of reason). The courts have been inconsistent in setting the precise standard for legality under the rule of reason. In some situations, the courts have held that "Ir]estraints of trade can be justified only in the absence of less restrictive alternatives." Siegel v. Chicken Delight, 448 F.2d 43, 51 (9th Cir. 1971), cert. denied, 405 U.S. 955 (1972); see also Copper Liquor, Inc. v. Adolph Coors Co., 506 F.2d 934, 942-43 (5th Cir. 1975) ("Any justification [for restraints of trade] should be premised on the absence of less restrictive alternatives."). Other courts have applied the less rigorous test of whether the restraint exceeds "the limits reasonably necessary to meet the competitive problems." United States v. Arnold, Schwinn \& Co., 388 U.S. 365, 380-81 (1966); American Motor Inns, Inc. v. Holiday Inns, Inc., 521 F.2d 1230, 1249 (3d Cir. 1975) (quoting Schwinn).

42. Likewise, the cost of some forms of advertising, such as television, is the same regardless of whether a small or a large organization is advertising. The existence of economies of scale can be inferred from the overhead costs of small and large charities. The American Cancer Society, for example, has an income of roughly $\$ 130$ million and an overhead of $13 \%$. The Epilepsy Foundation, by contrast, spends $40 \%$ of its $\$ 7.8$ million on fundraising. The overhead of the local chapters of the United Way of America is typically about $10 \%$. See Cook, supra note 1, at 48-51.

The imperfect information of donors is another source of economies of scale. Because donors are in a poor position to evaluate services, see supra note 28 , they are likely to prefer to deal with agencies that have name-recognition and a national reputation. See Rose-Ackerman, supra note 4, at 328 (suggesting that united charities have less to offer to established charities such as Red Cross than to less well-known organizations).

43. Although single charities do advertise their services and the news media do report egregious scandals involving charities, donors typically lack complete information about the availability and quality of services provided by charities. People who would perhaps donate to charity if they had sufficient information may not be willing to invest heavily in acquiring that information. 
tions that would otherwise be made. Because a donor cannot be sure of what a contribution will produce, he must discount the value of what he thinks his gift will accomplish by the probability that he will be wrong.

United charities reduce this uncertainty with their formal allocation and monitoring procedures. These procedures assure donors that their gifts will go to a charity that has been approved by an allocations committee and that the use of their funds will be overseen. For uninformed donors, these procedures can enhance the utility of making a gift by reducing the need for donors to evaluate services themselves. ${ }^{44}$

United charities also benefit some donors by assembling packages of services related to one another by an articulated or unarticulated theme. For example, some united charities, such as the Combined Health Agency Drive, consist of only health agencies. The members of others, such as the National Black United Fund, are linked by a racial theme. Still others, such as the United Jewish Appeal, have a religious orientation. To the extent that donors find the services provided by members of such united charities equally valuable, competition among the members for donations is socially unproductive: it merely increases the overhead of all members, thereby reducing the value of their services to donors. ${ }^{45}$ This packaging benefits donors by permitting them to delegate the task of allocating their funds.

\section{B. The Inefficiencies of United Charity Practices}

The regulations and policies of united charities suppress competition in many ways. Some of those restrictions are analogous to restraints that the Sherman Act prohibits in the for-profit sector. Their legality in the nonprofit sector depends on whether they are needed to create the efficiencies discussed above.

\section{Membership Restrictions}

Because of the competitive benefits of membership in a united charity, restrictions on admission naturally create Sherman Act concerns. Some restrictions, however, may be socially beneficial. First, a restrictive admissions process enables a united charity to ensure the quality of its membership. That practice benefits donors by assuring them that their gift will go to an agency that, in the judgment of the admissions committee, will respond to a community need. Second, by controlling membership, the managers of united charities can construct packages of charitable services they

44. See Rose-Ackerman, supra note 4, at 325-26.

45. See infra pp. 1606-07. 
believe will be particularly attractive to potential donors. ${ }^{46}$

But the managers of a united charity can also use the admissions process to advance their own interests at the expense of donors and other charities. By limiting competitors' access to payroll deduction plans, a united charity can increase competitors' fundraising costs significantly and thereby reduce competitors' attractiveness to donors.

Under the Sherman Act, a group that has monopoly power because of control of a particular resource cannot lawfully use that resource to disadvantage competitors arbitrarily or invidiously. ${ }^{47}$ The greater the competitive advantage of access to the resource, and the greater the market share affected, the more important that the resource be provided to competitors on a reasonable basis.

The cost advantage of united charity fundraising depends upon the relative efficiency of other forms of fundraising. ${ }^{48}$ The significance of that cost advantage must be considered in light of the united charity's share of all fundraising in the relevant market. For the purposes of determining market share in this context, the market should be defined geographically and by type of service. If a united charity represents only a small portion of the relevant market, the significance of its cost advantage will be minimal; most charities competing for solicitations will still be on an equal competitive footing.

If a united charity excludes new members because their services are inconsistent with its theme, a court must examine whether the united charity has advertised itself to be of a certain nature. ${ }^{49}$ Allowing charities to package themselves benefits donors by enabling them to support a known package of charitable services. Under the Sherman Act, therefore, a charity is excludable on this basis only if a typical donor would not consider it properly part of the package advertised by the united charity.

It is more difficult to determine an appropriate test when a united charity excludes an agency because of the doubtful quality of its services. Eval-

46. Depending on donor preferences, it may be more efficient to link a child health agency with other health agencies rather than with other child welfare agencies. The efficient groupings depend, of course, on the utility functions of potential donors.

47. See, e.g., Otter Tail Power Co. v. United States, 410 U.S. 366 (1973); Associated Press v. United States, 326 U.S. 1 (1945); United States v. Terminal R.R. Ass'n, 224 U.S. 383 (1912); Gamco, Inc. v. Providence Fruit \& Produce Bldg., Inc., 194 F.2d 484 (1st Cir.), cert. denied, 344 U.S. 817 (1952). Professor Sullivan summarizes these cases as follows:

We can generalize by saying that if a group of competitors, acting in concert, operate a common facility and if due to natural advantage, custom, or restrictions of scale, it is not feasible for excluded competitors to duplicate the facility, the competitors who operate the facility must give access to the excluded competitors on reasonable, non-discriminatory terms.

L. SUllivan, supra note 21 , at 131 .

48. For a discussion of the difficulties of fundraising methods other than payroll deductions, see Cook, supra note 1 , at $48-51$.

49. In many cases, the theme will be defined by the name of the united charity. 
uation of charitable services is extremely subjective. Still, substantive review on a limited basis is desirable to require a united charity to justify the particular exclusion. ${ }^{50}$ In addition, courts should review the admissions process to determine whether it has an inherently invidious bias. Existing members of a united charity are likely to oppose the admission of any agency if the new member might cause their own revenues to decline. ${ }^{\mathbf{S 1}}$ Such opposition may be for legitimate reasons, such as the agency's poor management, but it may also be motivated by a desire to suppress competition for limited funds. Courts should, therefore, approve an admissions procedure only if decisions are made by an economically disinterested board. ${ }^{\mathbf{} 2}$

\section{Restrictions on Supplemental Fundraising}

Many united charities require each member to agree to restrict its own solicitation activities in exchange for a share of the funds raised by the group. ${ }^{53}$ Such agreements, in effect, constitute horizontal market divisions of the sort that are illegal per se in the for-profit sector under section 1 of the Sherman Act. ${ }^{54}$

But restrictions on supplemental fundraising may be necessary to obtain some benefits of united charity fundraising. Without such restrictions, united charity members would have an incentive to conduct independent

50. See, e.g., Gamco, Inc. v. Providence Fruit \& Produce Bldg., Inc., 194 F.2d 484 (1st Gir.) (rejecting defendant's substantive justifications for excluding plaintiff from monopolized asset), cert. denied, 344 U.S. 817 (1952). This type of review can be analogized to judicial review of administrative actions. Some courts in this role have closely examined the substantive determinations on which agency action was based. See Greater Boston TV Corp. v. FCC, 444 F.2d 841 (D.C. Cir. 1970) (reviewing agency determination in detail), cert. denied, 403 U.S. 923 (1971).

51. See Rose-Ackerman, supra note 4, at 327-28.

52. See, e.g., United States v. Associated Press, 326 U.S. 1 (1945). That case held illegal an Associated Press by-law that gave existing members the power to veto the membership applications of competitors. The court did not force the Associated Press to open access completely, but it held that the criteria for admission could not include a consideration of whether the applicant was in competition with existing members. Id. at 20.

53. The restrictions of the United Way of New Haven appear typical. Supplemental fundraising is to be conducted so that it does not conflict with the United Way campaign. Such fundraising must focus on individuals having a personal and continuing interest in the agency, as in a membership drive, or else be based upon a "value received" philosophy in which a donor receives something of tangible value, as in a raffle or bake-sale. Samples or descriptions of any printed materials are to be submitted to the United Way prior to their distribution. No limits are placed on funds from public grants or fees for service. United Way of Greater New Haven, supra note 9 (fundraising section).

54. See, e.g., Timken Roller Bearing Co. v. United States, 341 U.S. 593 (1951); Addyston Pipe \& Steel Co. v. United States, 175 U.S. 211 (1899). Market divisions have been prohibited even when ancillary to a joint venture. See, e.g., United States v. Topco Assocs., Inc., 405 U.S. 596 (1972); United States v. Sealy, Inc., 388 U.S. 350 (1967).

Courts strike down horizontal market divisions on the view that they suppress competition without enhancing efficiency. In some respects, market divisions impede competition even more than pricefixing: by reducing competition, a division of markets insulates each firm from competition not only with respect to price but also with respect to service, quality, and innovation. Sec L. SULLIVAN, supra note 21 , at 224-25. 
fundraising drives, which would dissipate the advertising efficiency of a united charity. It is socially undesirable for charities to spend money on fundraising in competition with other charities whose services are close substitutes. ${ }^{55}$ The part of a donor's gift spent on additional fundraising only benefits the donor if the additional funds raised have a greater value to him than the amount of services that could have been produced instead. A donor that finds the services of many charities of equal value would benefit if those charities avoided fundraising competition and increased the output of their services.

The point is identical in form to criticisms of some advertising in the for-profit sector. ${ }^{56}$ And yet, under the Sherman Act the potential for socially wasteful competition has never justified agreements among for-profit producers to suppress competition. ${ }^{67}$ Courts have rigidly insisted on preserving competition in order to allow market forces to work.

But there is a difference between the for-profit and nonprofit sectors, however, that suggests that market divisions among charities (in the form of fundraising restrictions) should be excused even though they are prohibited among for-profit firms. Donors know considerably less about charitable services than consumers know about the products they purchase. In the for-profit sector, consumers obtain much of their information about products through experience using them. Such information reduces the importance of advertising. Donors, on the other hand, rarely have any firsthand experience with the services of the charity they support. Donors must therefore obtain virtually all of their information through advertising by the charity. Yet, dissemination of information sufficient for donors to make fully informed decisions concerning donations would be unduly expensive. ${ }^{58}$

55. See Rose-Ackerman, supra note 4, at 326; S. Rose-Ackerman, supra note 31 (demonstrating how an unregulated charity market will impose extremely high fundraising costs on charities).

56. See R. SCHMALENSEE, THE ECONOMICS OF ADVERTISING 6-7 (1972) (competition among producers of highly substitutable products is wasteful competition for market share).

57. In National Soc'y of Professional Eng'rs v. United States, 435 U.S. 679, 687-96 (1978), the Court rejected the argument that the particular characteristics of an industry might make competition undesirable and therefore make anticompetitive practices legal. Defendants claimed that unrestrained competitive bidding would cause engineers to cut costs in the area of safety, which would be against the public interest. The Court held that such a determination was for Congress to make, not the courts: "The Rule of Reason does not support a defense based on the assumption that competition itself is unreasonable." Id. at 696.

Courts have also consistently rejected attempts to justify the activity of cartels on the grounds that the prices they fix, the quotas they set, and the market divisions to which they agree are reasonable under the particular circumstances. See Timken Roller Bearing Co. v. United States, 341 U.S. 593 (1951) (market division); United States v. Trenton Potteries Co., 273 U.S. 392 (1927) (price-fixing). The courts' position is based in part upon a realization of the limits of judicial competence. For the courts to make such assessments would require them to "set sail upon a sea of doubt." United States v. Addyston Pipe \& Steel Co., 85 F. 271, 284 (6th Cir. 1898) (striking down price-fixing and market division scheme), modified and aff'd, 175 U.S. 211 (1899).

58. See S. Rose-Ackerman, supra note 31 (suggesting that unregulated charity market may cause 
It may therefore be desirable to reduce competitive advertising among charities and find other mechanisms to promote cost efficiency in the production of charitable services. The monitoring services of united charities serve this function by reducing the importance of well-informed donors. Moreover, allowing a united charity some selectivity in its membership reduces the need for wide dissemination of information: membership decisions can be made by a few well-informed people. A properly functioning united charity can, therefore, encourage efficient production of charitable services and avoid wasteful advertising competition.

The undesirable effects of reduced competition can be minimized if a united charity allows donors who feel adequately informed to allocate their donation to the charity of their choice. A united charity can encourage such donor choice by informing the public about the services performed by its members. Before concluding that a restriction on fundraising does not violate the Sherman Act, a court should determine that such information is being fairly and accurately disseminated.

\section{Restrictions on Allocations by Donors}

Many united charities effectively prevent an individual donor's preferences from affecting the relative level of support received by individual members. Donations typically go into a common fund and are divided by an allocations committee, often in advance of collection. Some united charities allow donors to designate the recipient of their particular gift, but such united charities usually take the designated gifts received by an agency into account when allocating the undesignated gifts. Thus, the designation by the donor typically has no effect on the amount of money that a member charity receives relative to other member charities.

Such allocation procedures are in many ways similar to "tie-in" sales. In the for-profit sector, this term refers to a sale in which a seller will sell his product to a buyer only in conjunction with a second product. ${ }^{50}$ When a donor gives to a united charity, his gift automatically supports all services produced by member agencies in the proportions determined by the allocations committee. In effect, allocation restrictions "tie" a donor's support of any united charity member to the support of all other members. ${ }^{60}$

charities to spend almost their entire budget on fundraising).

59. A common example is the case of a computer manufacturer that requires purchasers to buy its computer cards. The seller of the computer thus "ties" the sale of the "tying" product, the computer, to the buyer's purchase of the "tied" product, the computer cards. International Business Machines Corp. v. United States, 298 U.S. 131 (1936).

60. For a tie-in sale to be effective, the seller must possess market power in the tying product. Otherwise, consumers will obtain the good from other producers. For a seller to have market power, demand for the good must be inelastic over some range of price. When demand is inelastic, a small relative change in price results in an even smaller relative decrease in quantity demanded. Thus, a 
In the for-profit sector, the appropriate law governing tie-in arrangements is in dispute. Many courts have suggested that the sole purpose and effect of these arrangements is to extend the seller's monopoly power in one market into another market. Hence, courts have frequently held these arrangements illegal per se under section 1 of the Sherman Act. ${ }^{61}$ But many scholars defend tie-in arrangements on the grounds that they generate efficiencies without enabling a monopolist to increase his monopoly profits. ${ }^{62}$ Such scholars argue that a monopolist cannot extract from consumers any more value than his position in the monopolized product allows. It makes no difference whether he extracts his monopoly price by selling the product alone, or with another less desirable product. If he ties the sale of two products together, he must presumably reduce the price of the desirable product to reflect the undesirability of purchasing the second product.

The courts' view may be more persuasive when applied to tie-in sales by nonprofit producers. The defense of tie-in arrangements assumes that a for-profit seller can choose between tying the sale of one product to the sale of another, and selling the more desirable product alone at a monopoly price. A nonprofit monopolist does not exploit his position by explicitly raising his price. He can only exploit his position by promoting his interest at the expense of donors. ${ }^{63}$ He may, for example, tie the support of one charitable service to the support of other services that donors prefer less. ${ }^{64}$ A united charity that is prohibited from tying charitable services

price increase will increase total expenditure on the good even though fewer goods are produced.

In the nonprofit sector, the same effect may occur if demand for charitable services is inelastic. By producing services of less value to donors (that is, raising the "price"), charities may lead donors to spend more on charity even though the output of the desired services declines, as does donor utility. For a mathematical demonstration of this effect, see Fisher, On Donor Sovereignty and United Charities, 67 AM. ECON. REV. 632 (1977).

61. See, e.g., Northern Pac. Ry. Co. v. United States, 356 U.S. 1 (1958); International Salt Co. v. United States, 332 U.S. 392 (1947). Section 3 of the Clayton Act has also been used to attack tying arrangements, but it is not important for united charities because it applies only to transactions involving "goods, wares, merchandise, machinery, supplies, or other commodities." 15 U.S.C. § 14 (1976). Because the present analysis involves the sale of services, only $\S 1$ of the Sherman Act is considered, although any distinction between the standards under these two statutes appears now to have almost vanished. See L. SULlivaN, supra note 21, 432-41. But see Times-Picayune Publishing Co. v. United States, 345 U.S. 594, 605-10 (1953) (drawing distinction between Sherman Act and Clayton $\Lambda$ ct standards). At present, a tie-in arrangement violates the Sherman Act when it affects a substantial amount of commerce and when the tying product is significantly differentiated in the view of consumers. See L. Sullivan, supra note 21 , at 440 .

62. See R. BORK, supra note 21, at 365-81; Bowman, Tying Arrangements and the Leverage Problem, 67 YALE L.J. 19 (1957); Markovits, Tie-ins, Leverage, and the American Antitrust Laws, 80 Yale L.J. 195 (1970); Stigler, United States v. Loew's Inc.: A Note on Block-Booking, 1963 SUP. CT. REV. 152. But see C. KAYSEN \& D. TURNER, ANTITRUST POLICY 157-59 (1959); Burstein, A Theory of Full-Line Forcing, 55 Nw. U.L. REV. 62 (1960); Ferguson, Tying Arrangements and Reciprocity: An Economic Analysis, 30 LAW \& CONTEMP. PROBS. 552 (1965).

63. See supra p. 1601.

64. See Fisher, supra note 60. There are other ways for nonprofit monopolists to exploit their position, but existing safeguards already pretermit many of them. A nonprofit monopolist could, for 


\section{United Charities}

together will therefore be more responsive to donor desires.

The restriction on allocation by donors may, however, be necessary for a united charity to capture the full benefits of joint fundraising. Donor allocation gives each united charity member an incentive to advertise for itself to convince donors to designate it as the recipient of their donations. If each member believes others will follow this strategy, all will engage in outside advertising and the economy of joint advertising will be lost. ${ }^{85}$

Another way of preserving this efficiency, however, is to prohibit members from advertising on their own. ${ }^{68}$ Such a prohibition has its own drawbacks, but many united charities already have such a policy. It is difficult to determine which policy-restrictions on advertising by members, or restrictions on the allocation of funds by donors-is the more desirable means of preserving the benefits of united charities. It does seem, however, that both policies respond to the same problem, and that each would be a sufficient response. Thus, under the Sherman Act there is no justification for a united charity to follow both policies.

This analysis is not meant to imply that the role of the united charity in the allocations process should be eliminated entirely. The point is simply that a united charity may not both prevent a donor from allocating his gift to a particular agency and make it difficult for him to give to the agency directly by preventing the agency from soliciting him. Both practices are not "reasonably necessary" to preserve a united charity's efficiency. ${ }^{67}$ If a united charity decides to limit outside solicitations by its members, it must allow donors to allocate their donations when making gifts through the united charity. Of course, those donors who wish to delegate the responsibility for allocating their funds need not earmark their donations. ${ }^{68}$

\section{Boycotts and Concerted Refusals to Deal}

Some united charities refuse to solicit in workplaces where other charities are also allowed to solicit. ${ }^{69}$ An employer therefore may limit access to

example, exploit his position by unreasonably increasing the salaries of the charity's employees, but the monitoring procedures of united charities constrain such behavior.

65. See supra pp. 1605-07 (discussing justifications for fundraising restrictions).

66. Id.

67. See supra pp. 1601-02 (describing standards of legality under the rule of reason).

68. United charities should design their allocation procedures to serve both the interests of donors who want to allocate funds themselves and those who do not. For example, they might establish a special pool of funds for donors who do not want to allocate funds themselves, which the allocations committee could allocate without regard to the amount of designated funds received. Another possibility would be to distribute undesignated funds to each agency in proportion to the designated funds received by each.

69. See California State Combined Health Agencies Drive, Inc. v. United Way, No. 382,156 (Cal. Super. Ct. filed Aug. 16, 1977) (several employers terminated relationship with plaintiff after local United Way allegedly announced it would no longer solicit in workplaces where other campaigns were held). 
his workplace to one united charity even though he would otherwise allow several independent or united charities to solicit. ${ }^{70}$ This exclusivity produces inefficiencies in the production of charitable services. First, it increases the relative overhead costs of excluded charities that are denied access to the payroll deduction system. Second, it imposes search costs on donors who are not satisfied with the options provided by the united charity allowed to solicit in their workplace.

A united charity's demand for exclusive solicitation rights may be termed a concerted refusal to deal or a group boycott. The Supreme Court has, on occasion, implied that group boycotts are illegal per se, ${ }^{71}$ but in practice their treatment has varied according to circumstances. ${ }^{72}$ "Naked" boycotts, which aim to drive competitors out of business merely to suppress competition, have been held illegal per se. ${ }^{73}$ Boycotts used to enforce rules or practices upon the members of a group who break legitimate group norms have sometimes been found reasonable. ${ }^{74}$

If a united charity demands exclusive access to an employer's workplace, its goal must be to deny competitors the advantages of payroll deductions. An insistence on exclusive access suppresses competition without producing any socially desirable results. Such conduct therefore constitutes a per se violation of section 1 of the Sherman Act. $^{75}$

70. He would do so if he believes that the benefit to his frrm is greater with only one united charity soliciting than with any other set of united or independent charities. See id.

71. See, e.g., United States v. General Motors Corp., 384 U.S. 127 (1966); Klor's, Inc. v. Broadway-Hale Stores, Inc., 359 U.S. 207 (1959).

72. The legality of group boycotts under $\S 1$ of the Sherman Act depends primarily on the purpose of the concerted activity. A boycott clearly harms competitors; its legality depends on whether it serves a legitimate purpose, see Cement Mfrs. Protective Ass'n v. United States, 268 U.S. 588 (1925) (court upholding boycott designed to prevent buyers from placing fraudulent orders); Molinas v. National Basketball Ass'n, 190 F. Supp. 241 (S.D.N.Y. 1961) (upholding disciplinary action against basketball player suspended for betting on his team), or is an illegitimate attempt to suppress competition, see Eastern States Retail Lumber Dealers' Ass'n v. United States, 234 U.S. 600 (1914) (holding illegal attempt to induce retailers to refuse to deal with wholesalers who sold directly to customers); American Medical Ass'n v. United States, 130 F.2d 233 (D.C. Cir. 1942), aff'd, 317 U.S. 519 (1943). In American Medical Ass'n, the medical society warned hospitals that they might lose its approval if they opened their facilities to two former members. The court found the boycott illegal because it was not persuaded that the purpose of the members' expulsion was ethical rather than economic.

73. See, e.g., Fashion Originators' Guild, Inc. v. FTC, 312 U.S. 457 (1941); Eastern States Retail Lumber Dealers' Ass'n v. United States, 234 U.S. 600 (1914).

74. See supra note 72. A common context in which boycotts are found to be legal is that of selfregulated athletics. See Deesen v. Professional Golfers' Association of America, 358 F.2d 165, 170 (9th Cir. 1966) (upholding right of Professional Golfers' Association of America to restrict eligibility in PGA sponsored tournaments), cert. denied, 387 U.S. 1032 (1967); Molinas v. National Basketball Ass'n, 190 F. Supp. 241 (S.D.N.Y. 1961) (upholding disciplinary suspension of basketball player for betting on his team).

75. This conclusion does not imply that a united charity may not refuse to conduct campaigns in certain workplaces. A united charity has the right to avoid campaigns that are not "profitable." But a uniform policy that ignores the economic success of individual campaigns is dubious, and if its motivation is merely to make an already successful campaign even more successful by restricting donor choice, the illegality is clear. 
A more complicated issue is presented by united charities that do not demand exclusive access but do create strong incentives for employers to give them exclusive access. United charities typically provide public recognition for employers whose workers give particularly generously in the united charity campaign. Such awards can have significant public relations value for a firm. When an employer allows access to numerous united charities, the chances of his firm's making a good showing in any of the campaigns decline because employees will divide their generosity among the different charities. The employer is thus better off, from the perspective of public relations, if he limits access to a single united charity ${ }^{76}$ It is likely, moreover, that he will choose a large united charity because of the increased media coverage that it can attract.

A united charity should not be able to take advantage of the combined public significance of its members to create incentives for employers to deny access to smaller charities. On the other hand, the willingness of employers to give charities access to their workplaces at all is, in part, the result of the public relations value the employers gain. It would be a mistake to eliminate this benefit to employers, because it makes possible an extremely efficient form of generating goodwill. What the Sherman Act should prohibit are public relations schemes that unnecessarily create incentives for employers to limit access to their payroll deductions. Public relations schemes could be designed to create incentives for employers to provide more open access. Instead of giving awards based upon employee donations to a particular united charity, awards could be given based upon employees' total donations to all charities combined.

\section{Conclusion}

This analysis suggests that the benefits of united charities relate primarily to economic efficiency. Through their access to payroll deductions, united charities reduce the fundraising costs of their members; their monitoring procedures reduce the total cost of overseeing the use of gifts. Some united charity practices, however, restrict donor choices and therefore disadvantage those donors who wish to make their own allocative decisions.

The Sherman Act is a suitable tool for regulating united charities; it permits them to reduce fundraising costs while at the same time it prevents unreasonable restrictions on donor choice. United charities should operate as efficient fundraising conduits, enhancing donor choice rather than restricting it. The Sherman Act enables united charities to promote

76. The desire of employers to make a good showing in their annual campaign has on occasion led employers to pressure employees to contribute. See, e.g., C. BAKAL, supra note 5, at 409-11 (describing pressure tactics); N.Y. Times, Nov. 29, 1981, §1, at 40, col. 6 (dismissal of bank employee for refusing to donate). 
economic efficiency while at the same time it minimizes their interference with the autonomy of individual donors.

Appendix: The Economic Significance of Free Entry into the Charity Market

One of the conditions required for an unregulated market to achieve Pareto optimality is that firms price their output at marginal cost. ${ }^{1}$ Profitmaximizing firms do not produce at levels for which the marginal cost of production exceeds the price received for the good (a quantity to the right of $Q_{1}$, in Figure 1, where price equals $P_{1}$ ). A nonprofit firm, however, may produce at any level of output for which it can cover all costs, that is, any level at which donations cover the average cost of production ${ }^{2}$ (quantity to the left of $Q_{2}$, where price ${ }^{3}$ equals $P_{1}$ ). This tendency can result in allocative inefficiency.

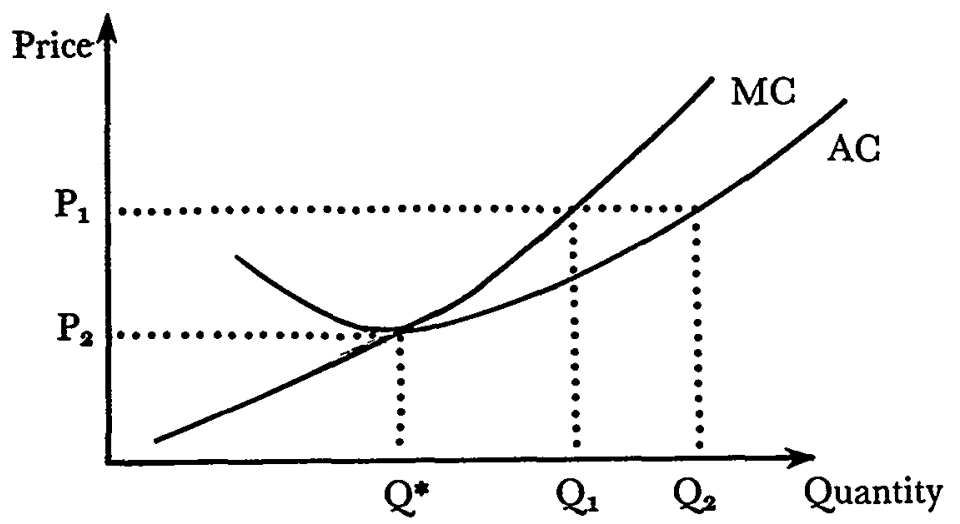

Figure 1

At any level of output greater than $Q^{*}$, however, new firms can enter

1. At this level of output, the sale price covers the cost of factor inputs for the last unit of ouput, but at a higher level of production, the price would not continue to do so. When marginal cost exceeds price, consumers would benefit if the factor inputs used to produce the last unit were instead used to produce an alternate good, the price of which covers its full cost of production.

2. Given the heterogeneity of nonprofit organizations, different nonprofits may pursue a variety of organizational goals (that is, output maximization, budget maximization, quality maximization). Their goals presumably reflect some combination of the interests of the organization's management and benefactors. See Newhouse, Toward a Theory of Nonprofit Institutions: An Economic Model of a Hospital, 60 AM. ECON. REV. 64 (1970) (postulating that nonprofit hospitals have two goals: $\max$ imization of output and maximization of quality); S. Rose-Ackerman, supra note 31, at 5 (postulating that united charities seek to maximize their budget net of fundraising costs).

3. The "price" of a charitable service is the amount of a donation required to generate an additional unit of services. A charity that is willing to produce more additional services with the same donation has a lower price for its services. 


\section{United Charities}

the market and offer charitable services at a lower price. Free entry will therefore pressure nonprofit firms to produce at the point of minimum average cost $\left(Q^{*}\right.$, at a price of $\left.P_{2}\right)$. This level of output equates average cost with marginal cost. Thus, free entry causes nonprofit firms to produce at marginal cost despite their lack of profit motive. If other competitive requirements hold, competition in the charity sector will result in an efficient allocation of resources."

4. See Scherer, supra note 26 (discussing conditions for general equilibrium efficiency). 